distance. The roof was bad, and required timbering. A long account of the Wealden iron industry is given by C. Gould in the Geological Survey Memoir "The Geology of the Weald" (1875), compiled by Topley, and additional information, notably an analysis of the Snape Wood ore, in the Geological Survey's "Special Reports on the Mineral Resources of Great Britain", 12 (1920). This analysis, made in 1908 for J. W. Gregory by Messrs. R. R. Tatlock and Thomson, showed the following, in percentages: $\mathrm{FeO}, 30.42$; $\mathrm{Fe}_{2} \mathrm{O}_{3}, 10 \cdot 10 ; \mathrm{SiO}_{2}, 26 \cdot 10 ; \mathrm{CaO}, 0 \cdot 86 ; \mathrm{SO}_{3}, 0 \cdot 06$. These show about 30.66 per cent of metallic iron, but the high percentage of $\mathrm{SiO}_{2}$ would prevent the use of this stone as an iron ore. On the contrary, the Ashburnham ore showed $\mathrm{FeO}, 42.08 ; \mathrm{Fe}_{2} \mathrm{CO}_{3}$, $6 \cdot 85 ; \mathrm{SiO}_{2}, 6 \cdot 46 ; \mathrm{CaO}, 3 \cdot 87 ; \mathrm{SO}_{3}, 0 \cdot 2$; giving $37 \cdot 49$ per cent of metallic iron, with relatively little silica. Unfortunately not only are the beds of ore thin, but they are also very irregular in their composition, and there seems little prospect that ore of this kind, which occurs in thin beds and can only be excavated together with a large amount of shale, could be profitably worked by existing methods. The usable reserves of iron ore in the Weald are, in the present circumstances, negligible.

\section{Awards of the Geological Society of London}

THE following awards of the Geological Society of London have recently been announced: Wollaston Medal to Prof. R. A. Daly, Sturgis Hooper professor of geology in the Museum of Comparative Geology at Harvard University, in recognition of his fundamental researches in many branches of geology, especially those concerned with the origin of igneous rocks, the constitution of the interior of the earth, and the controls of coral-reef formation; Murchison Medal to Prof. H. H. Swinnerton, professor of geology in University College, Nottingham, for his stimulating contributions to the philosophy of palæontology; Lyell Medal to Mr. W. S. Bisat, for his studies in the stratigraphical palæontology of Carboniferous rocks ; Wollaston Fund to Dr. E. S. Hills, for his contributions to Australian palæontology and geology; Murchison Fund to Dr. K. C. Dunham, for his investigations into the mineral deposits of the North of England; a moiety of the Lyell Fund to Dr. S. R. Nockolds, for his mineralogical and petrological work and his contributions to the study of assimilation processes; a second moiety of the Lyell Fund to Dr. J. Shirley, for his researches in palæozoic palæontology and stratigraphy.

\section{Institute of Metals : Platinum Medallist}

THE Platinum Medal of the Institute of Metals for 1942 has been awarded to Mr. W. Murray Morrison, vice-chairman and managing director of the British Aluminium Co., in recognition of his outstanding services to the non-ferrous metals industries. $\mathrm{Mr}$. Morrison is an original member and a fellow of the Institute of Metals, on the Council of which he served for sixteen years-in the last two as vicepresident. He may be described as the father of the aluminium industry in Great Britain, having been associated with the British Aluminium Co. since its inception in 1894. $\mathrm{He}$ is also the pioneer of the developments of Highland water-power upon which depend the electro-metallurgical operations for the production of aluminium at three great Scottish factoriss.
Institution of Mining and Metallurgy: New President

Mr. J. Alles Howe has been elected president of the Institution of Mining and Metallurgy for the year 1942-43. Mr. Allen Howe was educated privately and at the Royal College of Science, and holds the London B.Sc. degree. For a year he was demonstrator in geology at the Royal College of Science and Royal School of Mines, and in 1901 was appointed to H.M. Geological Survey, where he served for thirty years on the field staff and as curator of the Museum of Practical Geology, and from 1922 onwards as assistant director. During his service he took an active part in stimulating the economic side of the Survey's work, and he is the author of several works mainly dealing with building stone, broken stone, and refractory materials. On these and other subjects he has made numerous contributions, including many articles on topographical geology and stratigraphy in the Encyclopædia Britannica (thirteenth edition). He was a member of the International Conferences on Testing Materials, and was for a number of years adviser on stone to H.M. Office of Works and since 1918 to the Imperial War Graves Commission. He was a member of the Committee on Coal Conservation and the Imperial Economic Committee. Since $1931 \mathrm{Mr}$. Allen Howe has practised as a consultant in economic geology.

\section{Chronica Botanica}

THIs international plant science news magazine, formerly published in Holland, continues to appear now from Waltham, Mass., U.S.A. Vol. 6, Nos. 17-18 appeared in November 1941 and is an exceedingly interesting number. Under the heading "Nomina ad Infinitum" Dr. F. C. Bawden asks for a more vigorous effort to rationalize procedure in the naming of virus diseases of plants, and then in the "Plant Science Forum" a number of subjects of general botanical interest are raised by well-qualified contributors. Very general interest will be aroused by a brief note from Dr. W. C. Darrah on the fossil embryos in Iowa coal balls; in particular, in the record of the discovery of the embryo and young seedling of a Lepidocarpon. There then follows a series of brief "Progress Reports" on plant science in Latin America, for example, on forestry in Mexico (Meyer), natural resources of Costa Rica (Skutch), etc.

International activities naturally do not bulk largely in the present day, but there is a note on the International Forestry Centre, which, established in May 1939 as a division of the International Institute of Agriculture, held its third meeting in March 1940 in Berne. The "Chronicle" of events has a very full statement of Kew activities in view of the centenary of the Royal Botanic Gardens in 1941: there is an interesting account also of the All-Union Agricultural Fair held in Moscow during 1939 and 1940 and again re-opened in the early summer of 1941. Details of the activities and vicissitudes of various botanical departments under present disturbed conditions make interesting reading to botanists, and similarly the many changes in personnel chronicled will often bring news of colleagues to readers. Very naturally the editors have contemplated closing this venture with the completion of vol. 6, and the extension of the War to the Pacific will possibly force them to reconsider their present decision to proceed at least with the issue of Vol. 7 in the form of twelve numbers to be issued once every 
three months. If publication can be continued, how ever, this chronicle is probably more valuable to the botanical world under present conditions than even in normal times.

\section{Rapid Glass-house Repair}

THE problem of repairing small holes in glasshouses both rapidly and economically has confronted many growers since the outbreak of war. After a thorough investigation of the matter, the Cheshunt Experimental and Research Station recommends the use of Bostik B. glazing compound, manufactured by the B. B. Chemical Co., Ltd., Ulverscroft Works, Leicester. The glass must be clean and perfectly dry. An extending nozzle is fitted to the Bostik tube, by means of which a thick flat continuous bead of the compound is delivered. This is allowed to dry for five or six minutes. The piece of glass which is to serve as a patch is then pressed lightly down on to the bead and a further film of Bostik applied around the outer edge of the patch to complete the seal. Glass substitutes can be used for patching instead of glass, and cracks can be satisfactorily sealed by a bead of the compound. All particulars are given in War-Time Notes No. 1, issued with the annual report of the Cheshunt Research Station for 1940.

\section{Health of Eire}

According to the report of the Department of Local Government of Eire for 1939-40, 1939, as in all parts of the world from which statistics are available, was a record year in Eire owing to the low prevalence and fatality of acute infectious diseases. There were only 2,779 notifications of scarlet fever with 43 deaths in 1939 , both figures being much the lowest on record. There were 2,097 cases of diphtheria with 245 deaths which accounted for nearly two thirds of all deaths from endemic infections. The fatality rate of diphtheria, as in all parts of the world, unlike that of measles, whooping-cough, and scarlet fever, showed no tendency to fall. There was an apparent increase in the mortality from tuberculosis, but this was probably accounted for by an improvement in notification.

\section{Vital Statistics of Switzerland}

RECENT statistics show that the decline in the birth-rate in Switzerland still continues. In.1939 it exceeded the death-rate by only 3.4 per thousand inhabitants as compared with $3 \cdot 6$ in $1938,4 \cdot 2$ in $1936,5 \cdot 6$ in $1930,6 \cdot 5$ in $1920,9.9$ in 1910 and 11.5 in 1903. The death-rate reached its lowest record in 1934 and in 1937 with $11 \cdot 3$, but rose to $11 \cdot 6$ in 1938 and 11.8 in 1939. Since 1871, with few exceptions, the marriage-rate has fluctuated between 6.8 and 7.9 , and the marriage age of single men has risen from $28 \cdot 5$ to $28 \cdot 9$, and of single women from $26 \cdot 1$ to $26 \cdot 7$.

\section{Mechanism of the Sun}

THE presidential address to the British Astronomical Association was delivered on October 29 by F. J. Sellers, and dealt with the sun. Mr. Sellers is director of the Section of the Association dealing with the sun, and has done a. considerable amount of research along certain lines. He has designed a very useful form of spectroscope and also a form of vibrating slit mechanism for the spectro-helioscope, and is a keen observer of solar phenomena. His address covered a very extensive field; here it is sufficient to say that the most up-to-date information on nuclear reactions in the interior of the sun, sunspots, the corona, chromospheric eruptions, etc., was discussed. The address is printed in full in the Journal of the British Astronomical Association (52, $1 ; 1941$ ).

\section{The Night Sky in February}

The moon is full on February $1 \mathrm{dd} .9 \mathrm{~h} .12 \mathrm{~m}$. and new on February 15d. 10h. 2m. U.T. Lunar conjunctions with the planets occur on the following dates: Venus on February 14d. 0h., Venus $5^{\circ} \mathrm{N}$.; Mars on February 22d. 1h., Mars $6^{\circ} \mathrm{N}$. ; Saturn on February 22d. 3h., Saturn $3^{\circ} \mathrm{N}$.; Jupiter on February $23 \mathrm{~d}$. $19 \mathrm{~h}$., Jupiter $5^{\circ} \mathrm{N}$. Mercury is an evening star until February 8, then a morning star. Venus is a morning star, and Mars, Jupiter and Saturn are evening stars. On February 24d. 2h. Mars is in con. junction with Saturn, Mars being $3 \cdot 5^{\circ} \mathrm{N}$. Mars, Jupiter and Saturn are still well placed for observation during the month. The planet Uranus, seen as a 6th magnitude star, is in the western part of Taurus and about $5^{\circ}$ south of the Pleiades. In the latitude of London the day lengthens by about $1 \frac{3}{4}$ hours during the month.

\section{Announcements}

Dr. Selig HeCHT, professor of biophysics at Columbia University, has been awarded the Frederic Ives Medal of the Optical Society of America for "distinguished work in the field of optics".

The Pan-American League for the Control of Cancer will meet this year at Buenos Aires under the presidency of Prof. H. Angel Roffo.

THE International Commission on Continental and Oceanic Structure of the International Union of Geodesy and Geophysics (chairman, Dr. R. M. Field) has found means to continue in operation the Scoresbysund seismological station, originally run in connexion with Danish stations. Funds were granted by the American Philosophical Society of Philadelphia, which will supply paper and other photographic materials for another year of operation. The supplies have been shipped.

THE Rugby Branch of the Association of Scientific Workers is conducting a series of lectures and meetings, held on Thursdays, on the general theme, "The Coming Post-War World". Among the speakers are Prof. V. H. Mottram on the social implications of dietetics, Capt. J. Langdon Davies on scientific invention at the service of the community, and Prof. A. St. G. Huggett on the social basis of physical and psychological health. Particulars can be obtained from the honorary secretary; J. B. Laurie, Upper Rainsbrook, Ashlawn Road, Rugby.

THE Clough Memorial Research Fund was instituted in 1935 for the purpose of encouraging geological research in Scotland and the North of England. The North of England is defined as comprising the counties of Northumberland, Cumberland, Durham, Westmorland and Yorkshire. Under the terms of administration of the fund a sum of approximately $£ 30$ is available annually. Applications for grants are invited for the period April 1, 1942-March 31, 1943, and should be made to the Secretary, Clough Research Fund Committee, Edinburgh Geological Society, Synod Hall, Castle Terrace, Edinburgh, not later than March 1. 